\title{
A small molecule, (E)-2-methoxy-4-(3-(4-methoxyphenyl) prop- 1-en-1-yl) phenol suppresses tumor growth via inhibition of IkappaB kinase $\beta$ in colorectal cancer in vivo and in vitro
}

\author{
Jie Zheng ${ }^{1,3, *}$, Mi Hee Park ${ }^{1, *}$, Hee Pom Lee ${ }^{1}$, Byung Kook Hyun ${ }^{1}$, Hyung Ok Chun ${ }^{1}$, \\ Sung Hee Jung ${ }^{1}$, Hyun Ok Seo ${ }^{1}$, Young Wan Ham², Sang-Bae Han ${ }^{1}$ and Jin Tae \\ Hong ${ }^{1}$ \\ ${ }^{1}$ College of Pharmacy \& Medical Research Center, Chungbuk National University, Cheongju, Chungbuk 28160, Republic of \\ Korea \\ ${ }^{2}$ Department of Chemistry, Utah Valley University 800 W, University Pkwy, Orem, UT 84058, USA \\ ${ }^{3}$ Current address: Tumor Microenvironment Global Core Research Center, College of Pharmacy, Seoul National University, \\ Seoul, 08826, Republic of Korea \\ *These authors have contributed equally to this work \\ Correspondence to: Jin Tae Hong, email: jinthong@chungbuk.ac.kr
}

Sang-Bae Han, email: shan@chungbuk.ac.kr

Keywords: MMPP, colon cancer, IKK $\beta$, death receptor, tumor growth inhibition

Received: March 24, $2017 \quad$ Accepted: July 26, $2017 \quad$ Published: August 24, 2017

Copyright: Zheng et al. This is an open-access article distributed under the terms of the Creative Commons Attribution License 3.0 (CC BY 3.0), which permits unrestricted use, distribution, and reproduction in any medium, provided the original author and source are credited.

\section{ABSTRACT}

Here we report that a novel synthesized compound (E)-2-methoxy-4-(3-(4methoxyphenyl)prop-1-en-1-yl)phenol (MMPP) which exhibits better stability, druglikeness and anti-cancer effect than (E)-2,4-bis(p-hydroxyphenyl)-2-butenal (BHPB) that we previously reported. Of all newly synthesized BHPB analogues, MMPP showed the most significant inhibitory effect on colon cancer cell growth. Thus, we evaluated the anti-cancer effects and possible mechanisms of MMPP in vitro and in vivo. MMPP treatment $(0-15 \mu \mathrm{g} / \mathrm{mL})$ induced apoptotic cell death and enhanced the expression of cleaved caspase- 3 and cleaved caspase- 8 in a concentration dependent manner. Notably, the expression of death receptor (DR)5 and DR6 was significantly increased by MMPP treatment. Moreover, DR5 siRNA or DR6 siRNA transfection partially abolished MMPP-induced cell growth inhibition. Pull down assay and docking experiment showed that MMPP bound directly to IkappaB kinase $\beta$ (IKK $\beta$ ). It was noteworthy that IKK $\beta$ mutant (C99S) partially abolished MMPP-induced cell growth inhibition and enhanced expression of DR5 and DR6. In addition, MMPP enhanced TRAIL-induced apoptosis, cell growth inhibition and expression of DRs. In xenograft mice model, MMPP (2.5-5 mg/ $\mathrm{kg})$ suppressed tumor growth in a dose dependent manner. Immunohistochemistry analysis showed that the expression levels of DR5 and DR6 and active caspase-3 were increased while the expression levels of PCNA and p-IKK $\beta$ were decreased in a dose dependent manner. Thus, MMPP may be a promising anti-cancer agent in colon cancer treatment.

\section{INTRODUCTION}

Colorectal cancer (CRC, also known as colon cancer) is the third common cancer and the third leading cause of cancer death in both men and women [1]. About 54 percent of colorectal cancer cases occurred in more developed countries.
The highest incidence of colorectal cancer was in Oceania and Europe, and the lowest incidence in Africa and Asia. But Republic of Korea had the highest rate of colorectal cancer in recent years [2]. As present treatments for colon cancer patients are not so sufficient, it is urgent to develop appropriate novel chemo-preventive compounds with less toxicity. 
Nuclear factor kappa-light-chain-enhancer of activated $B$ cells $(\mathrm{NF}-\kappa \mathrm{B})$ plays a vital role on cell survival via inhibition of apoptosis and contribution of cancer development [3]. NF- $\mathrm{BB}$ is constitutively activated in various human cancer tissues and cell lines including colorectal cancer $[4,5]$. In general, NF- $\kappa \mathrm{B}$ signaling pathway is triggered by activation of IKK complex [6]. Phosphorylation of I $\kappa \mathrm{B} \alpha$ mainly depends on the I $\mathrm{B}$ kinase $\beta$ (IKK $\beta$ ) catalytic subunit of the IKK complex [6]. Greten et al. found that deletion of IKK $\beta$ in intestinal epithelial cells in a mouse model of colitis-associated model for cancer (CAC) dramatically reduced tumor number [7]. Moreover, impaired NF- $\kappa \mathrm{B}$ activation was observed in IKK $\beta$-deficient mice [8]. Thus, most chemopreventive agents suppressing NF- $\kappa \mathrm{B}$ by targeting IKK $\beta$ may show significant anti-cancer effect in colorectal cancer [9]. In our previous study, (E)-2,4-bis(p-hydroxyphenyl)-2-butenal (BHPB) suppressed colon tumor growth via inhibition of NF- $\kappa \mathrm{B}$ signaling pathway by targeting IKK $\beta[10]$.

Apoptosis can be induced through the activation of death receptors (DRs) such as Fas, DR3, DR4, DR5 and DR6 binding with each ligand [11-13]. These interactions induce apoptosis through activation of caspase families [12]. Recruitment of caspase- 8 through Fas associated death domain (FADD) leads to its acute-cleavage and activation $[14,15]$, and active caspase- 8 in turn activates effector caspases such as caspase-3 causing the cell to undergo apoptosis $[14,16]$. DR5 knockout mice are compromised in radiation induced apoptosis [17]. Activation of DRs could enhance susceptibility of cancer cells toward chemotherapeutics [18]. Numerous studies have demonstrated that DR signaling was correlated with cell death in colorectal cancer. It was previously found that bee venom, snake venom toxin, tectochrysin induced apoptosis via up-regulation of DRs in colon cancer cells [19-21]. These findings indicate that diverse activation of DRs depends on chemical properties.

Recently, we have found that BHPB showed anticancer effect [10, 22]. However, the existence of aldehyde functionality made the compound lack stability and druglikeness. To overcome the roadblock, we synthesized several BHPB analogues by Heck reaction which have more stable and proper drug-likeness properties than BHPB. We selected one analogue (E)-2-methoxy-4-(3(4-methoxyphenyl) prop-1-en-1-yl) phenol (MMPP), and evaluated the anti-cancer mechanisms and effects of MMPP on colon cancer cell growth in vivo and in vitro.

\section{RESULTS}

\section{MMPP inhibits colon cancer cell growth}

Cell viability was assessed by using MTT assay to evaluate the effect of MMPP on colon cancer cells.
MMPP $(0-20 \mu \mathrm{g} / \mathrm{mL}$ or $0-74 \mu \mathrm{M})$ inhibited colon cancer cell growth and $\mathrm{IC}_{50}$ values on HCT116 (Figure 1A) and SW480 (Figure 1B) were $12.00 \mu \mathrm{g} / \mathrm{mL}(44.39 \mu \mathrm{M})$ and $10.30 \mu \mathrm{g} / \mathrm{mL}(38.10 \mu \mathrm{M})$, respectively. However, in our previous study, $\mathrm{IC}_{50}$ of BHPB on HCT116 was $25 \mu \mathrm{g} / \mathrm{mL}$ $(98.31 \mu \mathrm{M})$. Notably, MMPP exhibited little toxicity on CCD-18Co colon epithelial normal cells (Figure 1C).

\section{MMPP induces apoptosis and regulates apoptosis-associated protein expression}

TUNEL assay was performed to determine whether the cell growth inhibition by MMPP was due to induction of apoptosis. The cells were treated with $\operatorname{MMPP}(0-15 \mu \mathrm{g} / \mathrm{mL})$ for 24 h, DAPI-stained TUNEL-positive cells were concentrationdependently increased and the highest concentration of MMPP (15 $\mu \mathrm{g} / \mathrm{mL}$ ) caused most of cells TUNEL-positive, and apoptosis rates were $67.95 \%$ in HCT116 cells (Figure 1D) and $61.26 \%$ in SW480 cells (Figure 1E).

Next, the expression of apoptotic proteins was investigated. MMPP $(0-15 \mu \mathrm{g} / \mathrm{mL})$ enhanced the expression of apoptotic proteins such as Bax, cleaved caspase- 3 and cleaved caspase- 8 while decreased the expression of anti-apoptotic protein Bcl-2 in HCT116 (Figure 2A) and SW480 (Figure 2B) colon cancer cells. These findings suggested that MMPP strongly induced apoptosis in HCT116 and SW480 colon cancer cells.

\section{MMPP directly binds to IKK $\beta$}

Structures of BHPB and MMPP were showed with Medchem designer 3.0 (Figure 3A). Structure of IKK $\beta$ was presented (Figure 3B). The molecular binding between MMPP and IKK $\beta$ was assessed by pull-down assay. The binding of MMPP-Sepharose $6 \mathrm{~B}$ beads with IKK $\beta$ was then detected by immunoblotting with IKK $\beta$ antibody. The results indicated that MMPP interacted with cell lysates containing IKK $\beta$ (Figure 3C). Molecular docking experiment revealed that MMPP directly bound to the ATP binding site of IKK $\beta$ with a strong binding affinity $(-8.2 \mathrm{kcal} / \mathrm{mol})$ (Figure 3D). Concretely, MMPP bound to hydrophobic binding pocket composed of Leu21, Val29, Tyr98, Cys99, Val152 and lleq65 (Figure 3E).

\section{MMPP suppresses phosphorylation of IKK $\beta$}

We performed Western blotting to investigate whether MMPP suppresses phosphorylation of IKK $\beta$ which is one of the main NF- $\kappa \mathrm{B}$ upstream signals. The results showed that phosphorylation of IKK $\beta$ and $\mathrm{I} \kappa \mathrm{B} \alpha$ were decreased (Figure $4 \mathrm{~A} \& 4 \mathrm{~B}$ ), and nuclear translocation of p50 and p65 were decreased in a concentration dependent manner in HCT116 (Figure 4C) and SW480 colon cancer cells (Figure 4D). 


\section{Abrogated effect of IKK $\beta$ mutant C99S with MMPP on cell growth and DR expression}

To further investigate the role of IKK $\beta$ on the anticancer effect of MMPP, the effect of IKK $\beta$ mutant C99S was investigated. Both cells were transfected with IKK $\beta$ mutant C99S for $24 \mathrm{~h}$, and then treated with MMPP for 24 $\mathrm{h}$ to assess cell viability and protein expression. MMPPinduced inhibitory effect on cell growth was partially abolished (Figure 5A) and MMPP-induced enhanced expression of DR5 and DR6 was partially abrogated (Figure 5B).

\section{Synergistic effect of TNF-related apoptosis- inducing ligand (TRAIL) with MMPP on cell growth and expression of DRs}

To investigate whether MMPP could enhance TRAIL induced apoptosis and cell growth inhibition, both cells were pre-treated with TRAIL for $2 \mathrm{~h}$, and treated with MMPP $(10 \mu \mathrm{g} / \mathrm{mL})$ for $24 \mathrm{~h}$ to assess apoptosis, cell viability and protein expression. As a result, MMPP augmented TRAIL-induced apoptosis (Figure 6A \& 6B), cell growth inhibition (Figure 6C \& 6D), enhanced the expression of DR5 and DR6 (Figure 6E \& 6F) in HCT116 and SW480 colon cancer cells.

\section{MMPP suppresses tumor growth in colon cancer xenograft model}

To demonstrate the anti-cancer effect of MMPP in vivo, the tumor growth on HCT116 xenograft nude mice following MMPP treatment was investigated. In HCT116 xenograft studies, MMPP $(2.5-5 \mathrm{mg} / \mathrm{kg})$ was administrated intraperitoneally twice per week for 3 weeks to mice with tumors ranging from $100-150 \mathrm{~mm}^{3}$. All mice were sacrificed at the end of experiment when tumors were dissected and weighted. The inhibitory effect of MMPP
A

HCT116

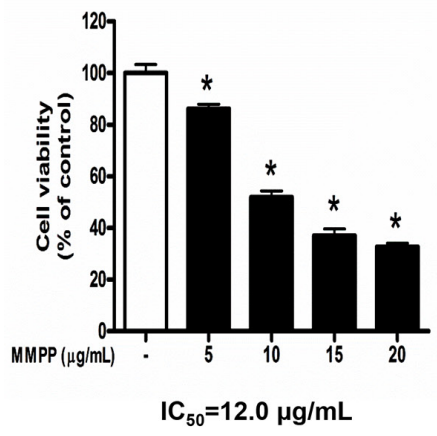

D

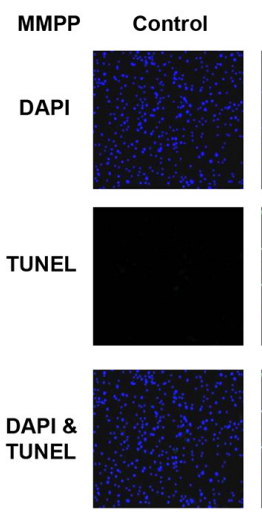

$15 \mu \mathrm{g} / \mathrm{mL}$
B

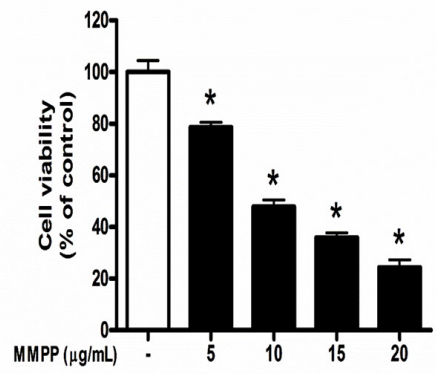

$\mathrm{IC}_{50}=10.3 \mu \mathrm{g} / \mathrm{mL}$

\section{$\mathrm{E}$}

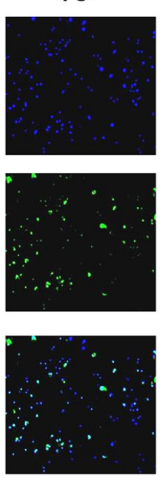

MMPP

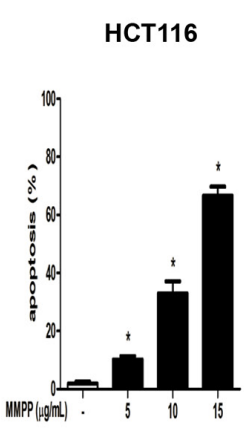

C

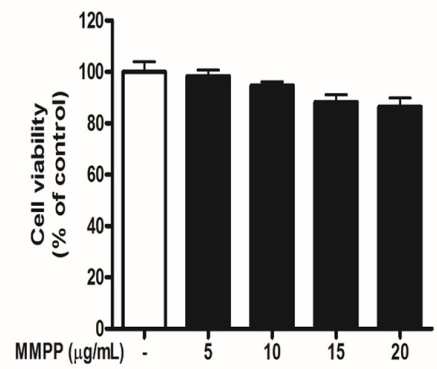

Figure 1: Effect of MMPP on the growth colon cancer cells and colon epithelial normal cells. Concentration-dependent inhibitory effect of MMPP on cancer cell growth was found in HCT116 and SW480 colon cancer cells but not in CCD-18Co colon epithelial normal cells. (A), (B) \& (C) HCT116, SW480 and CCD-18Co cells were treated with MMPP $(0-20 \mu \mathrm{g} / \mathrm{mL})$ for $24 \mathrm{~h}$, and then relative cell survival rate was determined by MTT assay. Data was expressed as the mean \pm S.D. of three experiments. ${ }^{*}<0.05$ indicates significant difference from control group. (D) \& (E) Apoptotic cell death of HCT116 and SW480. Colon cancer cells were treated with MMPP $(0-15 \mu \mathrm{g} / \mathrm{mL})$ for $24 \mathrm{~h}$, and then labeled with DAPI and TUNEL solution. Total number of cells in a given area was determined by using DAPI nuclear staining (fluorescent microscope). A green color in the fixed cells marks TUNEL-labeled cells. Apoptotic index was determined as the DAPI-stained TUNEL-positive cell number/total DAPI-stained cell number $\mathrm{x} 100 \%$. Data was expressed as the mean \pm S.D. of three experiments. ${ }^{*} p<0.05$ indicates significant difference from control group. 
A

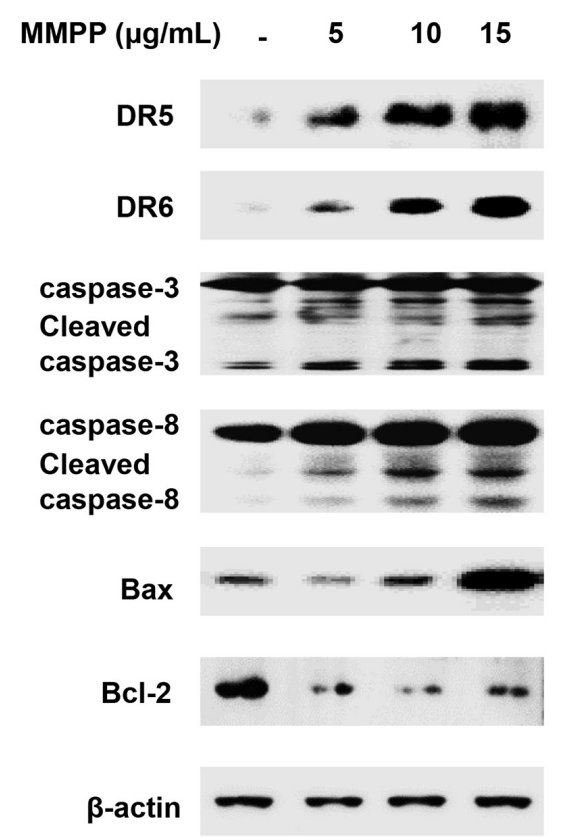

B

SW480

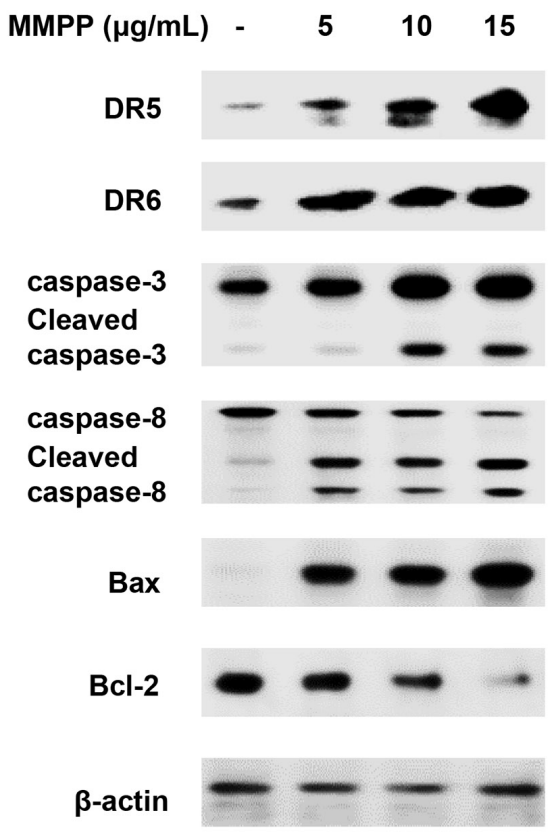

Figure 2: Effect of MMPP on apoptosis regulatory proteins in colon cancer cells. (A) \& (B) Expression of apoptosis regulatory proteins was determined by Western blot analysis with antibodies against DR5, DR6, cleaved capase-3, cleaved caspase-8, Bax, Bcl-2 and $\beta$-actin (internal control). Each band is representative for three experiments.

A

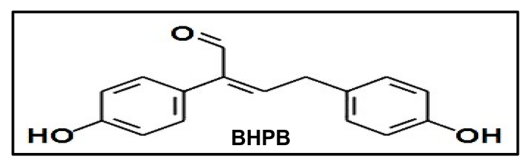

MOL.FORMULA $\mathrm{C}_{16} \mathrm{H}_{14} \mathrm{O}_{3}$

MOL.WEIGHT $\quad 254.28 \mathrm{~g} / \mathrm{mol}$

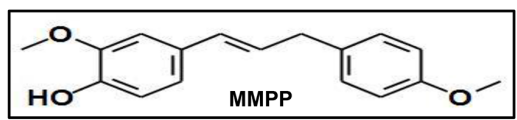

MOL.FORMULA $\mathrm{C}_{17} \mathrm{H}_{18} \mathrm{O}_{3}$

MOL.WEIGHT $\quad 270.33 \mathrm{~g} / \mathrm{mol}$

D

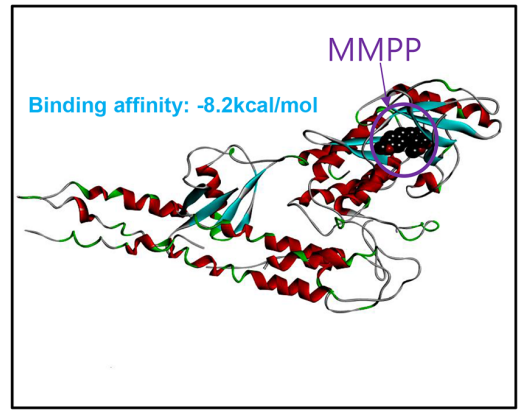

B

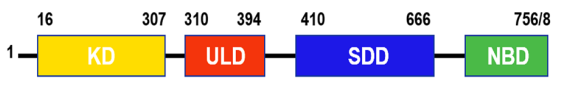

C

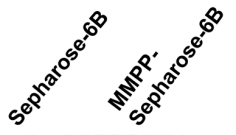

Ex vivo WB: IKK $\beta$

In put $\longrightarrow$ WB: IKK $\beta$

E

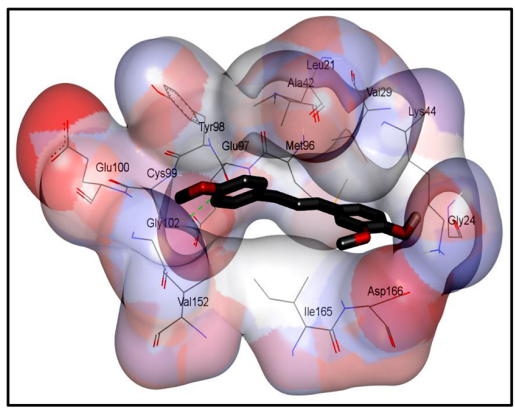

Figure 3: Structure of MMPP, and molecular binding between MMPP and IKKß. (A) (up) Structure of BHPB. (bottom) Structure of MMPP. (B) Structure of IKK $\beta$. (C) Pull-down assay identifies molecular binding between MMPP and IKK $\beta$. MMPP was conjugated with epoxy-activated Sepharose 6B. (D) \& (E) Docking model of MMPP with IKK $\beta$ was performed as described in the materials and methods. 
A

HCT116

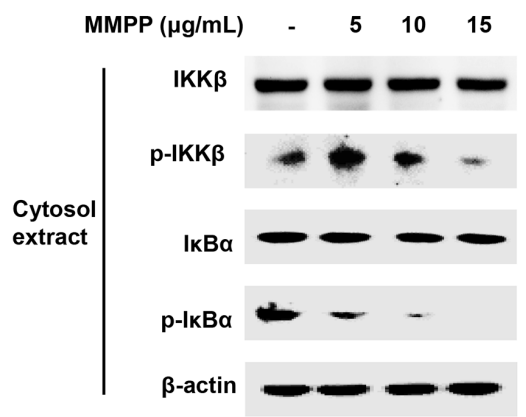

C

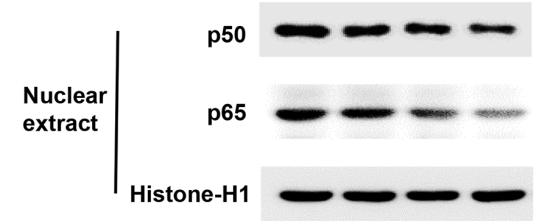

B

SW480

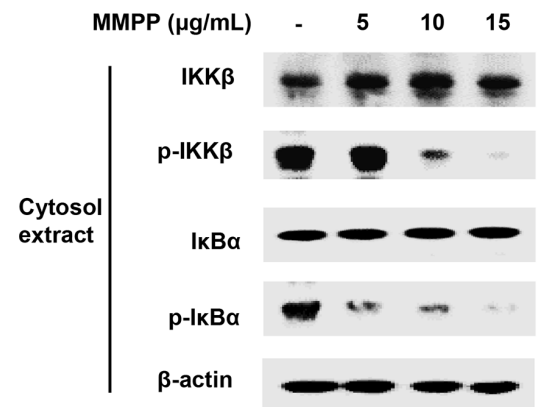

D

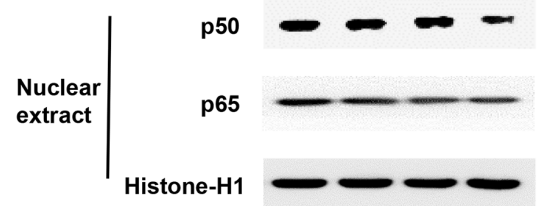

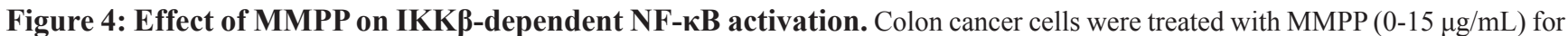
$2 \mathrm{~h}$, and then were lysed with A buffer and C buffer. (A) \& (B) Cytosol proteins were used to determine the expression of IKK $\beta$, p-IKK $\beta$, $\mathrm{I} \kappa \mathrm{B} \alpha, \mathrm{p}-\mathrm{I} \kappa \mathrm{B} \alpha$ and $\beta$-actin (internal control). (C) \& (D) Nuclear proteins were used to determine the expression of, p50, p65 and Histone H1 (internal control) in colon cancer cells. Each band is representative for three experiments.

A

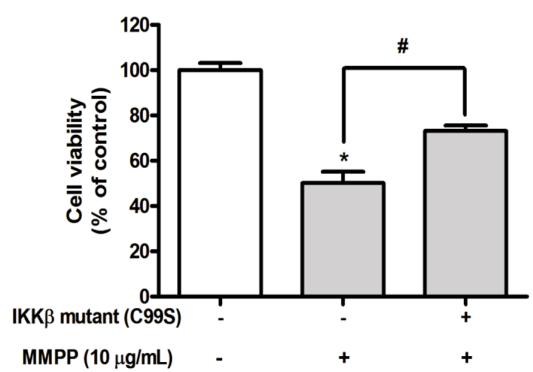

B

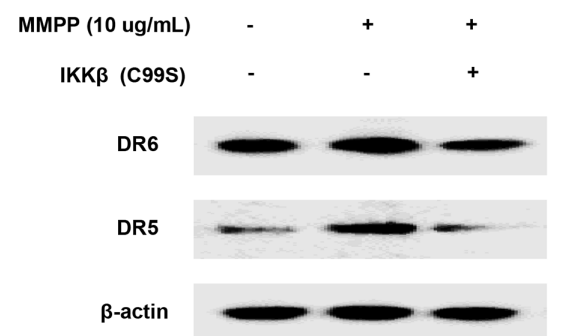

SW480

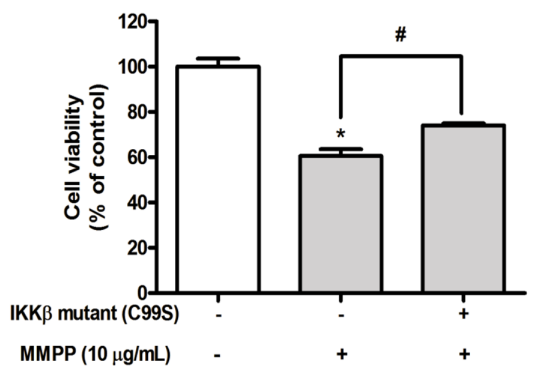

SW480

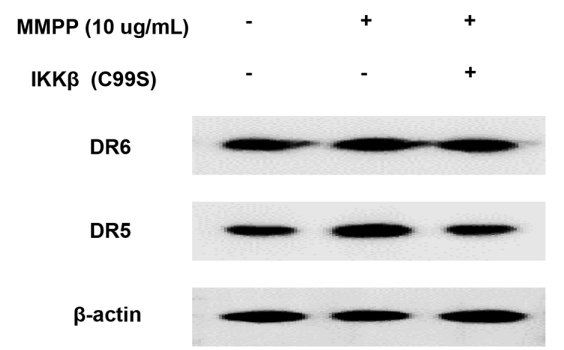

Figure 5: Effect of IKK $\beta$ mutant (C99S) on MMPP-induced inhibitory effect of cell growth, enhanced expression of DRs. (A) Cells were transfected with IKK $\beta$ mutant (C99S) for $48 \mathrm{~h}$, and then treated with MMPP (10 $\mu \mathrm{g} / \mathrm{mL})$ for $24 \mathrm{~h}$. Relative cell survival rate was determined by MTT assay. Data was expressed as the mean \pm S.D. of three experiments. ${ }^{*} p<0.05$ indicates significant difference from control group. (B) Protein expression was determined with Western blotting with antibodies against DR5, DR6 and $\beta$-actin (internal control). 
on tumor growth was significant in xenograft mice model (Figure 7A). Tumor volume and tumor weight were dosedependently decreased (Figure 7B \& Figure 7C). The immunohistochemistry analysis revealed that MMPP dose-dependently suppressed tumor growth, and enhanced the expression levels of DR5, DR6 and active-caspase-3 while decreased the expression levels of $\mathrm{p}$-IKK $\beta$ in nude mice xenograft tissues (Figure 7D).

\section{Effect of MMPP on the expression of apoptosis regulatory proteins in colon xenograft tumor tissues}

Western blotting was carried out to examine the relationship between tumor growth and apoptosis
HCT116

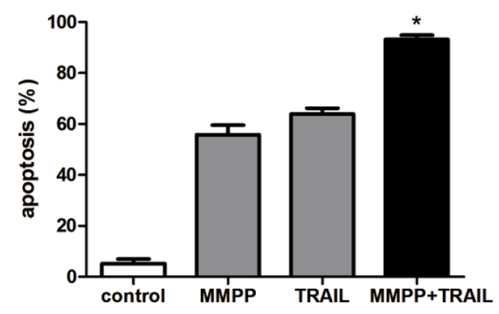

C

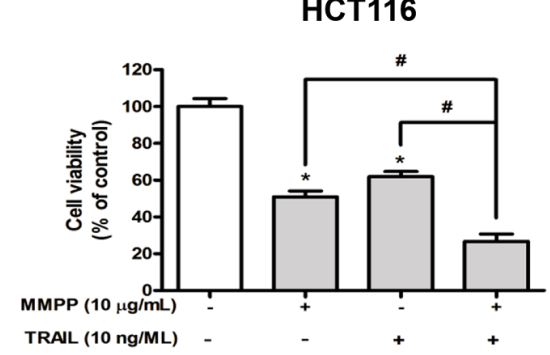

$\mathrm{E}$

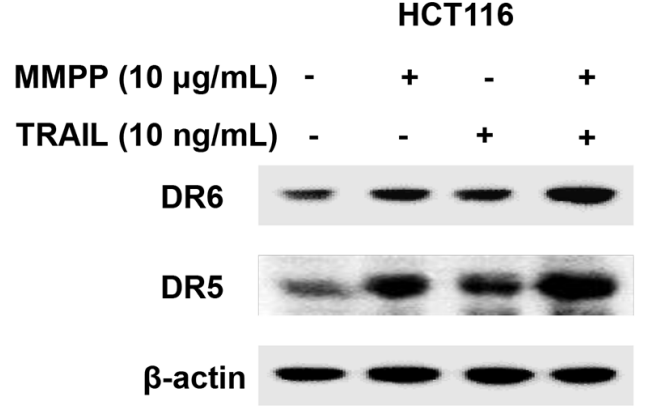

regulatory proteins, as well as $\mathrm{NF}-\kappa \mathrm{B}$ activity. We found that the expression of cleaved caspase-3, cleaved caspase- 8 and Bax was increased in a dose dependent manner $(2.5-5 \mathrm{mg} / \mathrm{kg})$ while the expression of Bcl-2 was decreased (Figure 8A). We also found the phosphorylation of IKK $\beta$, I $\mathrm{B} \mathrm{B} \alpha$ and the translocation of p50 and p65 were decreased in a dose dependent manner $(2.5-5 \mathrm{mg} / \mathrm{kg})$ (Figure 8B \& 8C) in colon xenograft tumor tissues.

\section{DISCUSSION}

In the present study, MMPP suppressed tumor growth of colon cancer in a dose dependent manner $(2.5-5 \mathrm{mg} / \mathrm{kg})$ via up-regulation of DR5, DR6 and inhibition of IKK $\beta$ / NF- $\kappa \mathrm{B}$ activity in HCT116 xenograft nude mice model.

B

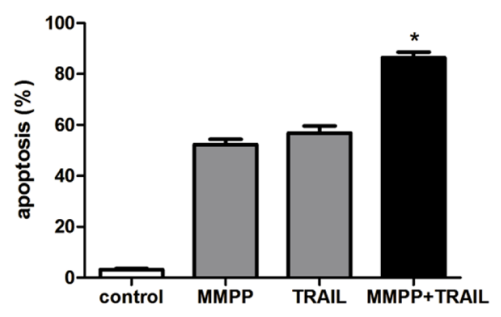

D

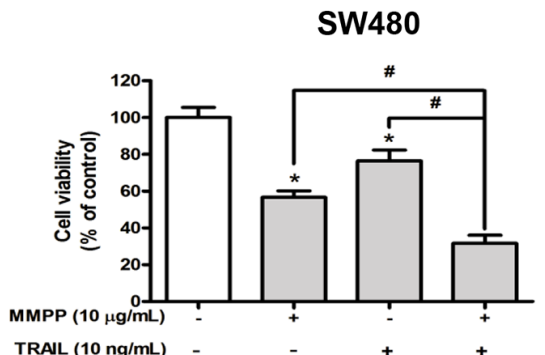

F

Figure 6: Effect of co-treatment with TRAIL and MMPP on apoptosis, cell growth and expression of DRs. (A) \& (B) Colon cancer cells were pre-treated with TRAIL recombinant protein $(10 \mathrm{ng} / \mathrm{mL})$ for $2 \mathrm{~h}$, and then treated with MMPP $(10 \mu \mathrm{g} / \mathrm{mL})$ for 24 h. Apoptotic index was determined as the DAPI-stained TUNEL-positive cell number/total DAPI-stained cell number $\mathrm{x} 100 \%$. Data was expressed as the mean \pm S.D. of three experiments. ${ }^{*} p<0.05$ indicates significant difference from control group. (C) \& (D) Relative cell survival rate was determined by MTT assay. Data was expressed as the mean \pm S.D. of three experiments. ${ }^{*} p<0.05$ indicates significant difference from control group. (E) \& (F) Protein expression was determined with Western blotting with antibodies against DR5, DR6 and $\beta$-actin (internal control). 
In addition, MMPP inhibited colon cancer cell growth by apoptosis induction, and inhibition of IKK $\beta / \mathrm{NF}-\kappa \mathrm{B}$ in HCT116 and SW480 colon cancer cells in vitro. These effects were correlated with the enhanced expression of various apoptotic proteins such as Bax, cleaved caspase-3 and cleaved caspase-8. However, the expression of antiapoptotic proteins such as Bcl-2 was decreased. Notably, the expression of DRs such as DR5 and DR6 was dramatically increased by MMPP concentration-dependently.

Tumor tissues obtained from colon cancer patients showed extremely high levels of $\mathrm{NF}-\kappa \mathrm{B}$ activity [23]. Suppressing NF- $\kappa \mathrm{B}$ with diverse approaches such as siRNA, IKK inhibitors and $\mathrm{I} \kappa \mathrm{B} \alpha$ suppressor inhibited survival and proliferation of cancer cells [24]. Suppression of NF- $\kappa \mathrm{B}$ involves targeting various components or steps in the NF- $\mathrm{B}$ signaling pathway such as inactivation of IKK, degradation of I $\mathrm{B} \alpha$, nuclear translocation and DNA binding activity of NF- $\kappa \mathrm{B}$ [2426]. Among these targets, IKK was thought to be the most effective and selective drug target [27]. Various studies have proposed that inhibition of NF- $\kappa \mathrm{B}$ signaling pathway by targeting IKK $\beta$ may play a vital survival role in colon cancer. A limonoid triterpene, Nimbolide inhibits growth of human colon cancer xenografts by inhibition of IKK activation [28]. (E)-2,4-bis(p-hydroxyphenyl)2-butenal suppressed colon tumor growth via inhibition of NF- $\kappa \mathrm{B}$ by targeting IKK $\beta$ [10]. Similarly, the present data showed that MMPP suppressed colon tumor growth via targeting IKK $\beta$. It was noteworthy that molecular docking experiment revealed that MMPP directly bound
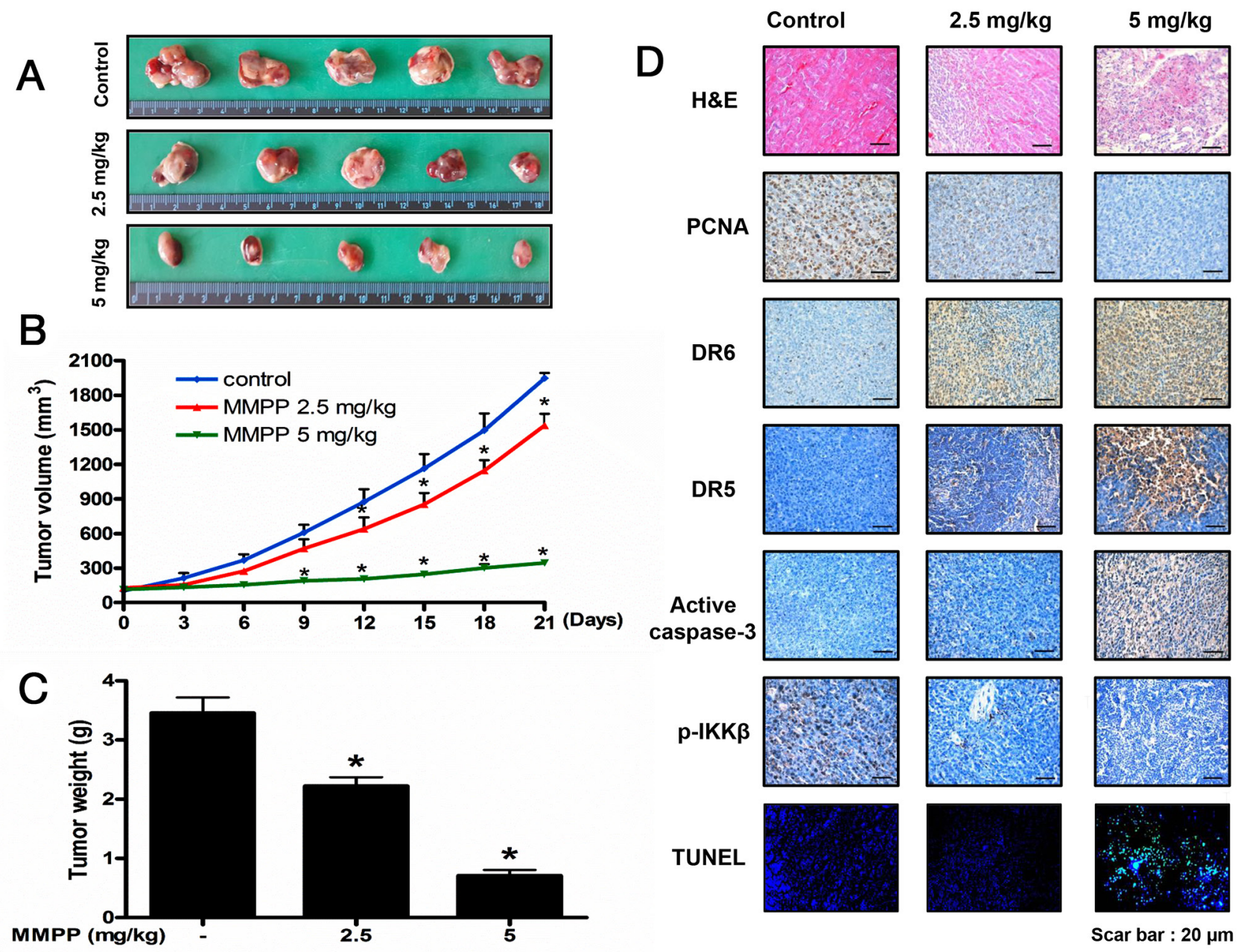

p-IKK $\beta$
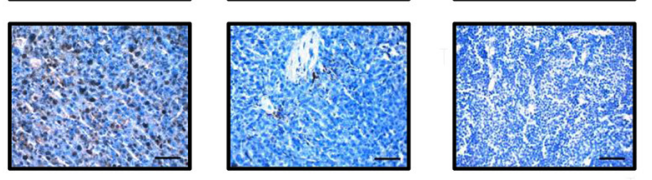

TUNEL
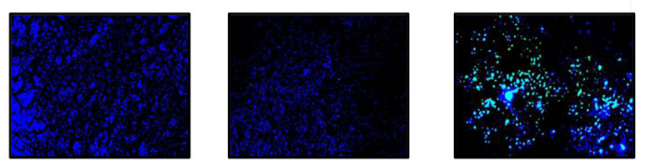

Scar bar : $20 \mu \mathrm{m}$

Figure 7: Anti-tumor activity of MMPP in colon cancer xenograft mice model. (A), (B) \& (C) Growth inhibition of subcutaneously transplanted HCT116 xenograft mice treated with MMPP (2.5 mg/kg and $5 \mathrm{mg} / \mathrm{kg}$ twice a week) for 3 weeks. Xenograft mice $(\mathrm{n}=10)$ were administrated intraperitoneally with $0.01 \%$ DMSO or MMPP $(2.5 \mathrm{mg} / \mathrm{kg}$ and $5 \mathrm{mg} / \mathrm{kg})$. Tumor burden was measured once per week using a caliper, and calculated volume length $(\mathrm{mm}) \times$ width $(\mathrm{mm}) \times$ height $(\mathrm{mm}) / 2$. Tumor weight and volume are presented as means \pm S.D. (D) Immunohistochemistry was used to determine expression levels of PCNA, DR6, DR5, active caspase-3, p-IKK $\beta$ in nude mice xenograft tissues by the different treatments as described in the materials and method. DAPI\&TUNEL assay was carried out to assess the apoptosis rate in the nude mice xenograft tissue. Total number of cells in a given area was determined by using DAPI nuclear staining (fluorescent microscope). A green color in the fixed cells marks TUNEL-labeled cells. 
to the ATP binding site of IKK $\beta$, hydrophobic binding pocket composed of Leu21, Val29, Tyr98, Cys99, Val152 and lleq65. Interestingly, the binding affinity of MMPP and IKK $\beta$ was $-8.2 \mathrm{kcal} / \mathrm{mol}$, and the binding domain was the same location as the known inhibitor [29]. However, in our previous study, the binding affinity of BHPB and IKK $\beta$ was -7.3 to $-8.0 \mathrm{kcal} / \mathrm{mol}$. This finding indicated that more stable structure contributed to the higher binding affinity with IKK $\beta$. In addition, pull down assay also showed that MMPP directly bound to IKK $\beta$ recombinant protein. In addition, MMPP-induced inhibitory effect on cell growth was partially abolished in C99S mutated IKK $\beta$. This may be because MMPP could not bind to C99S mutated IKK $\beta$, thereby exhibiting no significant anti-cancer effect. Therefore, IKK $\beta / N F-\kappa B$ signaling plays a critical role on MMPP-induced cell growth inhibition and apoptotic cell death.

Inhibition of NF- $\mathrm{BB}$ by blocking activation of IKK sensitizes tumor cells to TRAIL-induced apoptosis [30]. TRAIL selectively induces apoptosis of a variety of tumor cells and transformed cells, but not most normal cells [31]. Present findings showed that co-treatment with TRAIL and MMPP enhanced TRAIL-induced apoptosis and cell growth inhibition, and magnified the expression of DR5 and DR6. These effects were found to be synergistic because combination index (CI) value was evaluated and found smaller than 1 . These data indicated that inhibitory effect on IKK/NF- $\mathrm{BB}$ signaling by MMPP could enhance TRAIL-induced apoptosis. Notably, inhibition of NF- $\mathrm{KB}$ by several chemotherapeutics exposures human cancer cells to induction of apoptosis through activation of DRs [32]. Recent studies on the signaling mechanisms of DR have revealed that members of the NF- $\kappa \mathrm{B}$ are key regulators of apoptotic cell death [33]. Moreover, it was also well-documented that NF$\kappa \mathrm{B}$ directly up-regulates anti-apoptotic proteins such as C-FLIP which is a specific inhibitor of caspase- 8 to block caspase- 8 activity [34]. Our findings showed that MMPP suppressed phosphorylation of IKK $\beta$ and I $\mathrm{B} \alpha$, nuclear translocation of p50 and p65 and induced apoptotic cell death via regulating $\mathrm{DR} /$ caspase signaling. These data indicated that MMPP can inhibit colon cancer cell growth through induction of DR5 and DR6 via inhibition of IKK $\beta / \mathrm{NF}-\kappa \mathrm{B}$ signaling in vivo and in vitro.

In addition, BHPB showed plausible in mutagenicity in vivo and chromosome damage in vitro while MMPP

B
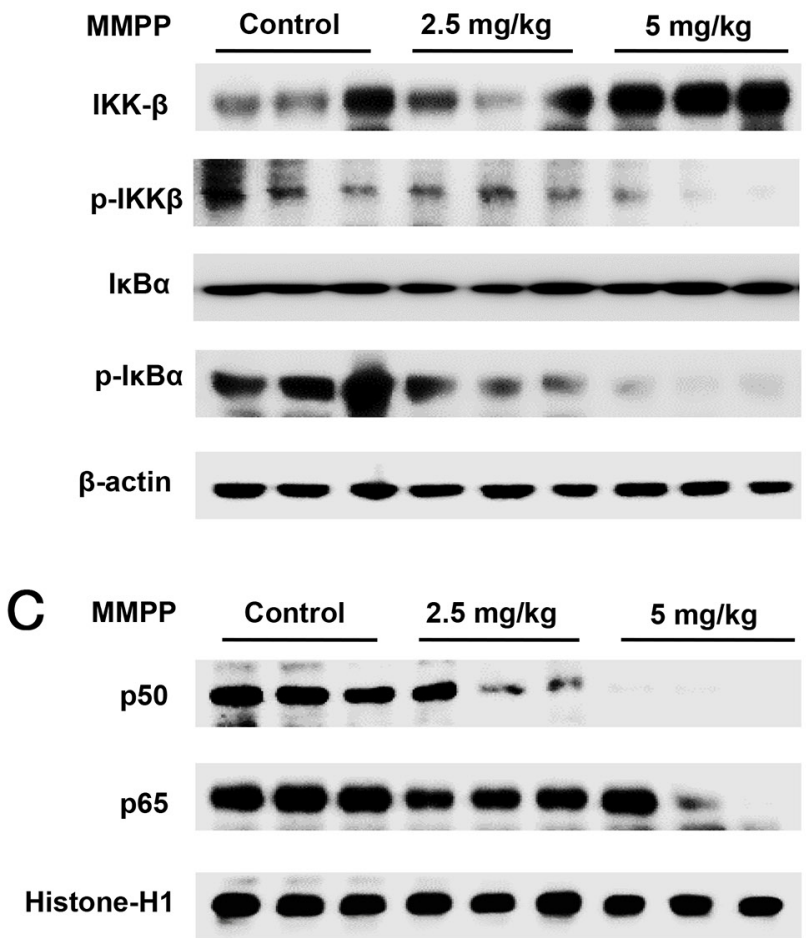

Figure 8: Effect of MMPP on the expression of apoptosis regulatory proteins, $\mathbf{N F - \kappa B}$ associated and subunit proteins. (A) Expression of apoptosis regulatory proteins was determined by Western blot analysis with antibodies against DR5, DR6, cleaved capase-3, cleaved caspase-8, Bax, Bcl-2 and $\beta$-actin (internal control). (B) Cytosol proteins were used to determine the expression of $\operatorname{IKK} \beta, \mathrm{p}-\mathrm{IKK} \beta, \mathrm{I} \kappa \mathrm{B} \alpha, \mathrm{p}$-I $\kappa \mathrm{B} \alpha$ and $\beta$-actin (internal control). (C) Nuclear proteins were used to determine the expression of, $\mathrm{p} 50$, $\mathrm{p} 65$ and Histone-H1 (internal control) in xenograft tumor tissues. Each band is representative for three experiments. 
showed negative on predicted toxicities, and MMPP showed better aqueous solubility, human intestinal absorption and skin permeability on predicted ADME [35]. Therefore, MMPP exhibits potentiality of clinical trial for colorectal cancer treatment.

\section{MATERIALS AND METHODS}

\section{Chemicals}

MMPP was synthesized and identified as previously described [35]. MMPP is dissolved in DMSO in the present study.

\section{Materials}

Caspase- 3 and caspase- 8 antibodies were purchased from Cell Signaling Technology Inc. (Beverly, MA, USA). Fas, DR3, DR4, DR5, DR6, IKK $\beta$, p-IKK $\beta$, IкB $\alpha$, p-IкB $\alpha$, p50, p65, Bcl-2, Bax, Histone-H1 and $\beta$-actin antibodies were purchased from Santa Cruz Biotechnology, Inc. (Santa Cruz, CA, USA). The cell culture materials were obtained from $\mathrm{GIBGO}^{\circledR}$ of Introgen ${ }^{\mathrm{TM}}$ (Seoul, Korea).

\section{Cell culture}

HCT116 and SW480 colon cancer or CCD-18Co colon epithelial cells were obtained from American Type Culture Collection (ATCC, Manassas, VA, USA). Both cells were from 3-passage stocks and were used before passage 30. The cells were tested to detect mycoplasma contamination using an e-MycoTM plus mycoplasma PCR detection kit (iNtRON Biotechnology, Seongnam, Gyeonggi, Korea). HCT116 and CCD-18Co cells were cultured in DMEM supplemented with 10\% heat inactivated FBS, 100 units/mL penicillin and $100 \mu \mathrm{g} /$ $\mathrm{mL}$ streptomycin. SW480 cells were cultured in RPMI supplemented with $10 \%$ heat inactivated FBS, 100 units/ $\mathrm{mL}$ penicillin and $100 \mu \mathrm{g} / \mathrm{mL}$ streptomycin. Cells were maintained in an incubator within a humidified atmosphere of $5 \% \mathrm{CO}_{2}$ at $37^{\circ} \mathrm{C}$.

\section{Cell viability assay}

HCT116 and SW480 colon cancer or CCD-18Co colon epithelial cells were seeded in 96-well plates, next day were treated with MMPP $(0-15 \mu \mathrm{g} / \mathrm{mL})$ for $24 \mathrm{~h}$. Cell viability assay was performed as previously described [35].

\section{Detection of Apoptosis}

HCT116 and SW480 colon cancer cells were plated in 8-chamber slides, next day were treated with MMPP $(0-15 \mu \mathrm{g} / \mathrm{mL})$ for $24 \mathrm{~h}$. TdT-mediated dUTP nick and labeling (TUNEL) assays were performed as previously described [35].

\section{Western blotting}

HCT116 and SW480 colon cancer cells were treated with MMPP $(0-15 \mu \mathrm{g} / \mathrm{mL})$ for $24 \mathrm{~h}$, then were homogenized with a protein extraction solution (PRO-PREP ${ }^{\mathrm{TM}}$, iNtRON Biotechnology, Seongnam, Gyeonggi, Korea), and lysed by $60 \mathrm{~min}$ incubation on ice. Western blotting was described elsewhere [36]. After a short washing in TBST, the membranes were immunoblotted with the following primary antibodies: caspase-3 and caspase- 8 (1:1000 dilutions; Cell Signaling, Beverly, MA, USA) and Fas, DR3, DR4, DR5, DR6, IKK $\beta$, p-IKK $\beta$, I $\mathrm{B} \alpha, \mathrm{p}-\mathrm{I} \kappa \mathrm{B} \alpha, \mathrm{p} 50$, p65, Bcl-2, Bax, Histone-H1 and $\beta$-actin (1:1000 dilutions; Santa Cruz Biotechnology, Santa Cruz, CA, USA). The blots were performed using specific antibodies followed by second antibodies and visualization by chemiluminescence (ECL) detection system.

\section{Plasmid construction}

C99S mutated IKK $\beta$ (C, a core amino acid of ATP binding site of IKK $\beta$ was replaced with an unrelated acid S) was generated by Cosmo Genetech (Seoul, Korea) and the mutants were checked by sequencing. HCT116 and SW480 colon cancer cells were plated in 6-well plates $\left(2 \times 10^{5}\right.$ cells / well $)$ and were transiently transfected with Mutated IKK $\beta$ (C99S), using the Lipofectamine 3000 reagent in OPTI-MEM for $48 \mathrm{~h}$ according to the manufacturer's specification (Invitrogen, Carlsbad, CA, USA). The transfected cells were treated with MMPP $(10 \mu \mathrm{g} / \mathrm{mL})$ for $24 \mathrm{~h}$ and then were used for detecting cell viability and protein expression.

\section{Antitumor activity study in in vivo xenograft animal model}

Seven-week-old male BALB/C nude mice were purchased from Orient-Bio (Seongnam, Gyunggi, Korea). The mice were maintained in accordance with the Korea Food and Drug Administration guidelines as well as the regulations for the care and use of laboratory animals of the animal ethics committee of Chungbuk National University (CBNU-278-11-01). HCT116 colon cancer cells were injected subcutaneous $\left(1 \times 10^{7}\right.$ cells / $0.1 \mathrm{~mL}$ PBS/animals) with a 27-gauge needle into the right lower flanks in carrier mice. After 14 days, when the tumors had reached an average volume of $100-150 \mathrm{~mm}^{3}$, the tumorbearing nude mice were intraperitoneally (i.p.) injected with MMPP $(2.5 \mathrm{mg} / \mathrm{kg}$ and $5 \mathrm{mg} / \mathrm{kg}$ dissolved in $0.01 \%$ DMSO) twice per week for 3 weeks. The group treated with $0.01 \%$ DMSO was designated as the control. The weight and tumor volume of the animals were monitored twice per week. The tumor volumes were measured with vernier calipers and calculated by the following formula: $\left(\mathrm{A} \times \mathrm{B}^{2}\right) / 2$, where $\mathrm{A}$ is the larger and $\mathrm{B}$ is the smaller of the two dimensions. At the end of the experiment, the 
animals were sacrificed. The tumors were separated from the surrounding muscles and dermis, excised and weighed.

\section{Immunohistochemistry}

Animals were sacrificed by $\mathrm{CO}_{2}$, tumor tissues were collected. Immunohistochemistry assay was performed as described elsewhere [36]. Staining was carried out using antibodies against PCNA, p-IKK $\beta$, active caspase-3, DR5 and DR6 (1:500, Abcam, Cambridge, UK).

\section{Pull-down assay}

MMPP was conjugated with epoxy-activated Sepharose 6B. Pull-down assay was performed as described elsewhere [36]. MMPP (1 mg) was dissolved in $1 \mathrm{~mL}$ of coupling buffer $\left(0.1 \mathrm{M} \mathrm{NaHCO}_{3}, \mathrm{pH} 13.0\right.$ containing $0.5 \mathrm{M} \mathrm{NaCl}$ ). The proteins were resolved by SDS-PAGE followed by immunoblotting with antibodies against IKK $\beta$ (1:1000 dilutions, Santa Cruz Biotechnology, Santa Cruz, CA, USA).

\section{Docking experiment}

Docking studies between IKK $\beta$ and MMPP was performed using Autodock VINA [37]. IKK $\beta$ crystal structure was used in the docking experiments and conditioned using AutodockTools by adding all polar hydrogen atoms. Three dimensional structures of IKK $\beta$ DNA complexes were retrieved from the Protein Data Bank (PDB codes: 3BRT). Starting from the co-crystallized complexes, the IKK $\beta$ monomer chain (IKK $\beta$ from 3BRT), MMPP for docking were prepared using Maestro graphical interface. The grid box was centered on the IKK $\beta$ monomer and the size of the grid box was adjusted to include the whole monomer. Docking experiments were performed at various exhaustiveness values of the defaults: 16, 24, 32, 40 and 60. Molecular graphics for the best binding model was generated using Discovery Studio Visualizer 2.0.

\section{Statistical analysis}

All statistical analysis was performed with GraphPad Prism 5 software (Version 5.0, GraphPad Software, Inc., San Diego, CA, USA). Group differences were analyzed using one-way ANOVA followed by Dunnett's test or twoway analysis of variance followed by Tuckey's test. All values are presented as mean \pm S.D. Significance was set at $p<0.05$ for all tests.

\section{Abbreviations}

BHPB: (E)-2,4-bis(p-hydroxyphenyl)-2-butenal; CI: combination index; DR: death receptor; FADD: Fas-associated death domain; IKK $\beta$ : IkappaB kinase $\beta$; MMPP: (E)-2-methoxy-4-(3-(4-methoxyphenyl)prop-1- en-1-yl)phenol; NF-кB: nuclear factor kappa-light-chainenhancer of activated $\mathrm{B}$ cells;

\section{Author contributions}

J.Z., M.H.P., S.B.H. and J.T.H. designed the experiments and wrote the manuscript. J.Z. and M.H.P. performed most of the experiments. B.K.H., H.O.C., S.H.J. and H.O.S. performed some Western blots and MTT assay. H.P.L. and Y.W.H. provided key reagents. Y.W.H. performed the docking study. J.Z., M.H.P., H.P.L., Y.W.H., S.B.H. and J.T.H. analyzed the data. J.T.H. supervised the overall research, secured funding, designed the experiments, interpreted results and wrote the manuscript. All authors reviewed the manuscript.

\section{CONFLICTS OF INTEREST}

The authors declare that they have no competing interests.

\section{GRANT SUPPORT}

This work was financially supported by the National Research Foundation of Korea [NRF] Grant funded by the Korea government (MSIP) (No. MRC, 2017R1A5A2015541), by the Ministry of Trade, Industry \& Energy (MOTIE, 1415139249) through the fostering project of Osong Academy-Industry Convergence (BAIO) and by the Functional Districts of the Science Belt Support program, Ministry of Science, ICT and Future Planning.

\section{REFERENCES}

1. Siegel R, Ma J, Zou Z, Jemal A. Cancer statistics, 2014. CA Cancer J Clin. 2014; 64:9-29.

2. Ferlay J, Soerjomataram I, Dikshit R, Eser S, Mathers C, Rebelo M, Parkin DM, Forman D, Bray F. Cancer incidence and mortality worldwide: sources, methods and major patterns in GLOBOCAN 2012. International journal of cancer. 2015; 136:E359-386.

3. Karin M, Cao Y, Greten FR, Li ZW. NF-kappaB in cancer: from innocent bystander to major culprit. Nat Rev Cancer. 2002; 2:301-310.

4. Sakamoto K, Maeda S. Targeting NF-kappaB for colorectal cancer. Expert opinion on therapeutic targets. 2010; 14:593-601.

5. Kojima M, Morisaki T, Sasaki N, Nakano K, Mibu $\mathrm{R}$, Tanaka M, Katano M. Increased nuclear factor-kB activation in human colorectal carcinoma and its correlation with tumor progression. Anticancer research. 2004; 24:675-681.

6. Ghosh S, Karin M. Missing pieces in the NF-kappaB puzzle. Cell. 2002; 109:S81-96. 
7. Basseres DS, Baldwin AS. Nuclear factor-kappaB and inhibitor of kappaB kinase pathways in oncogenic initiation and progression. Oncogene. 2006; 25:6817-6830.

8. Tanaka M, Fuentes ME, Yamaguchi K, Durnin MH, Dalrymple SA, Hardy KL, Goeddel DV. Embryonic lethality, liver degeneration, and impaired NF-kappa B activation in IKK-beta-deficient mice. Immunity. 1999; 10:421-429.

9. Bharti AC, Aggarwal BB. Nuclear factor-kappa B and cancer: its role in prevention and therapy. Biochemical pharmacology. 2002; 64:883-888.

10. Ban JO, Jung YS, Kim DH, Park KR, Yun HM, Lee NJ, Lee HP, Shim JH, Jeong HS, Lee YH, Ham YW, Han SB, Hong JT. (E)-2,4-Bis(p-hydroxyphenyl)-2-butenal inhibits tumor growth via suppression of NF-kappaB and induction of death receptor 6. Apoptosis. 2014; 19:165-178.

11. Schneider P, Tschopp J. Apoptosis induced by death receptors. Pharmaceutica acta Helvetiae. 2000; 74:281-286.

12. Inoue N, Matsuda F, Goto Y, Manabe N. Role of celldeath ligand-receptor system of granulosa cells in selective follicular atresia in porcine ovary. The Journal of reproduction and development. 2011; 57:169-175.

13. Yoshida T, Horinaka M, Sakai T. "Combination-oriented molecular-targeting prevention" of cancer: a model involving the combination of TRAIL and a DR5 inducer. Environmental health and preventive medicine. 2010; 15:203-210.

14. Thorburn A. Death receptor-induced cell killing. Cellular signalling. 2004; 16:139-144.

15. Salvesen GS, Dixit VM. Caspase activation: the inducedproximity model. Proceedings of the National Academy of Sciences of the United States of America. 1999; 96:10964-10967.

16. Fischer U, Janicke RU, Schulze-Osthoff K. Many cuts to ruin: a comprehensive update of caspase substrates. Cell death and differentiation. 2003; 10:76-100.

17. Finnberg N, Gruber JJ, Fei P, Rudolph D, Bric A, Kim SH, Burns TF, Ajuha H, Page R, Wu GS, Chen Y, McKenna WG, Bernhard E, et al. DR5 knockout mice are compromised in radiation-induced apoptosis. Molecular and cellular biology. 2005; 25:2000-2013.

18. Jo M, Park MH, Kollipara PS, An BJ, Song HS, Han SB, Kim JH, Song MJ, Hong JT. Anti-cancer effect of bee venom toxin and melittin in ovarian cancer cells through induction of death receptors and inhibition of JAK2/STAT3 pathway. Toxicology and applied pharmacology. 2012; 258:72-81.

19. Zheng J, Lee HL, Ham YW, Song HS, Song MJ, Hong JT. Anti-cancer effect of bee venom on colon cancer cell growth by activation of death receptors and inhibition of nuclear factor kappa B. Oncotarget. 2015; 6:44437-44451. doi: 10.18632/oncotarget.6295.

20. Park MH, Jo M, Won D, Song HS, Han SB, Song MJ, Hong JT. Snake venom toxin from Vipera lebetina turanica induces apoptosis of colon cancer cells via upregulation of
ROS- and JNK-mediated death receptor expression. BMC cancer. 2012; 12:228.

21. Park MH, Hong JE, Park ES, Yoon HS, Seo DW, Hyun BK, Han SB, Ham YW, Hwang BY, Hong JT. Anticancer effect of tectochrysin in colon cancer cell via suppression of NF-kappaB activity and enhancement of death receptor expression. Molecular cancer. 2015; 14:124.

22. Kollipara PS, Jeong HS, Han SB, Hong JT. (E)-2,4-bis(phydroxyphenyl)-2-butenal has an antiproliferative effect on NSCLC cells induced by 38 MAPK-mediated suppression of NF-kappaB and up-regulation of TNFRSF10B (DR5). British journal of pharmacology. 2013; 168:1471-1484.

23. Yu LL, Yu HG, Yu JP, Luo HS, Xu XM, Li JH. Nuclear factor-kappaB p65 (RelA) transcription factor is constitutively activated in human colorectal carcinoma tissue. World journal of gastroenterology. 2004; 10:3255-3260.

24. Chen W, Li Z, Bai L, Lin Y. NF-kappaB in lung cancer, a carcinogenesis mediator and a prevention and therapy target. Front Biosci (Landmark Ed). 2011; 16:1172-1185.

25. Lin Y, Bai L, Chen W, Xu S. The NF-kappaB activation pathways, emerging molecular targets for cancer prevention and therapy. Expert opinion on therapeutic targets. 2010; 14:45-55.

26. Shen HM, Tergaonkar V. NFkappaB signaling in carcinogenesis and as a potential molecular target for cancer therapy. Apoptosis. 2009; 14:348-363.

27. Karin M, Yamamoto Y, Wang QM. The IKK NF-kappa B system: a treasure trove for drug development. Nature reviews Drug discovery. 2004; 3:17-26.

28. Gupta SC, Prasad S, Sethumadhavan DR, Nair MS, Mo YY, Aggarwal BB. Nimbolide, a limonoid triterpene, inhibits growth of human colorectal cancer xenografts by suppressing the proinflammatory microenvironment. Clinical cancer research. 2013; 19:4465-4476.

29. Xu G, Lo YC, Li Q, Napolitano G, Wu X, Jiang X, Dreano M, Karin M, Wu H. Crystal structure of inhibitor of kappaB kinase beta. Nature. 2011; 472:325-330.

30. Ravi R, Bedi GC, Engstrom LW, Zeng Q, Mookerjee B, Gelinas C, Fuchs EJ, Bedi A. Regulation of death receptor expression and TRAIL/Apo2L-induced apoptosis by NF-kappaB. Nature cell biology. 2001; 3:409-416.

31. Wang S, El-Deiry WS. TRAIL and apoptosis induction by TNF-family death receptors. Oncogene. 2003; 22:8628-8633.

32. Nakanishi C, Toi M. Nuclear factor-kappaB inhibitors as sensitizers to anticancer drugs. Nature reviews Cancer. 2005; 5:297-309.

33. Sancho-Martinez I, Martin-Villalba A. Tyrosine phosphorylation and CD95: a FAScinating switch. Cell cycle. 2009; 8:838-842.

34. Chen F, Castranova V, Shi X. New insights into the role of nuclear factor-kappaB in cell growth regulation. The American journal of pathology. 2001; 159:387-397. 
35. Zheng J, Son DJ, Lee HL, Lee HP, Kim TH, Joo JH, Ham YW, Kim WJ, Jung JK, Han SB, Hong JT. (E)-2-methoxy4-(3-(4-methoxyphenyl)prop-1-en-1-yl)phenol suppresses ovarian cancer cell growth via inhibition of ERK, STAT3. Molecular carcinogenesis. 2017.

36. Zheng J, Park MH, Son DJ, Choi MG, Choi JS, Nam KT, Kim HD, Rodriguez K, Gann B, Ham YW, Han SB, Hong JT. (E)-4-(3-(3,5-dimethoxyphenyl)allyl)-2-methoxyphenol inhibits growth of colon tumors in mice. Oncotarget. 2015; 6:41929-41943. doi: 10.18632/oncotarget.5861.
37. Trott O, Olson AJ. AutoDock Vina: improving the speed and accuracy of docking with a new scoring function, efficient optimization, and multithreading. Journal of computational chemistry. 2010; 31:455-461. 